\title{
ANALISIS DAN DETEKSI MALWARE DENGAN METODE HYBRID ANALYSIS MENGGUNAKAN FRAMEWORK MOBSF
}

\author{
Edward Tansen, Deris Wahyu Nurdiarto \\ Program Studi Teknik Komputer, Universitas Amikom Yogyakarta \\ J1. Ring Road Utara, Ngringin, Condongcatur, Kec. Depok, Kabupaten Sleman, Daerah Istimewa Yogyakarta \\ edward.tansen77@students.amikom.ac.id, deris.n@students.amikom.ac.id
}

\begin{abstract}
The increase in the popularity of smartphones is followed by an increase in the number of users each year. In this case, smartphones with the Android platform are still ranked number one in the percentage of the highest number of users in the world. This fact is also followed by an increasing number of attacks by malicious programs or malware on the Android platform. These rogue application developers take advantage of the loopholes in the Android platform by inserting their malicious programs in the form of source code in Android applications and disseminating them through internet blogs and the Android application market. Ignorance and carelessness in lay users in installing android applications make the main target by malicious application developers. It is crucial to know by users what functions are performed by the Android application, especially in providing permissions or access rights to the Android system. This study, using a sample of Bouncing Golf and Riltok Banking Trojan malware. The study was conducted to know the characteristics and behavior using a combination of static analysis and dynamic analysis, or what is referred to in this study is a hybrid analysis using the MobSF framework. The analysis showed that Bouncing Golf stole information and was able to hijack infected Android devices effectively and Riltok Banking Trojan could take over mobile phones to steal information from credit cards through phishing techniques.
\end{abstract}

Keywords - Android; Dynamic Analysis; Hybrid Analysis; Malware; Static Analysis.

Abstrak - Peningkatan popularitas smartphone diikuti dengan kenaikan jumlah pengguna pada setiap tahunnya. Dalam hal ini, smartphone dengan platform android masih menjadi urutan nomor satu dalam persentase jumlah pengguna terbanyak di dunia. Fakta ini juga diikuti dengan meningkatnya jumlah serangan program jahat atau malware terhadap platform android. Para pengembang aplikasi jahat ini memanfaatkan celah yang ada pada platform android dengan menyisipkan program jahat mereka dalam bentuk source code di dalam aplikasi android dan menyebarluaskannya melalui blogblog internet serta pasar aplikasi android. Tidak adanya kewaspadaan dan lengahnya pada pengguna awam dalam memasang aplikasi android menjadikan target utama oleh pengembang aplikasi jahat. Sangat penting untuk diketahui oleh para pengguna terkait apa saja fungsi yang dilakukan oleh aplikasi android, terutama dalam memberikan perizinan atau hak akses terhadap sistem android. Dalam penelitian ini menggunakan sampel malware Bouncing Golf dan Riltok Banking Trojan. Penelitian dilakukan dengan tujuan mengetahui karakteristik dan perilaku dengan menggunakan kombinasi analisis statis dan analisa dinamis, atau yang disebut dalam penelitian ini adalah analisis hybrid menggunakan framework MobSF. Analisis yang dilakukan menunjukkan bahwa Bouncing Golf melakukan pencurian informasi dan dapat secara efektif membajak perangkat android yang terinfeksi dan Riltok Banking Trojan memiliki kemampuan dalam mengambil alih smartphone untuk mencuri informasi dari kartu kredit melalui teknik phishing.

Kata Kunci - Android; Dynamic Analysis; Hybrid Analysis; Malware; Static Analysis.

\section{PENDAHULUAN}

Menganalisa suatu malware sudah menjadi hal yang umum dilakukan dan menjadi ilmu dasar dari digital forensic. Untuk menjadi seorang investigator, menganalisa suatu perangkat lunak yang berbahaya adalah hal yang menantang dalam setiap melakukan investigasi [1]. Hal ini dikarenakan serangan malware yang meningkat dengan pesat dari dari tahun ke tahun.
Incident Monitoring Report Dwi Bulan III Persentase Pengaduan per Kategori Mei-Juni 2018

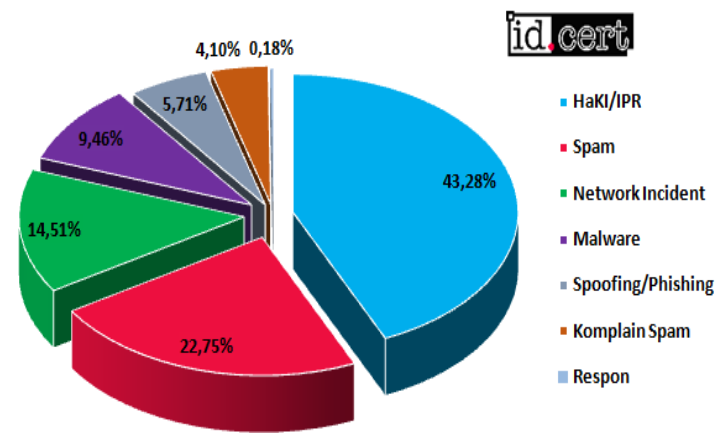

Gambar 1. Kategori Pengaduan Cybercrime 
Gambar 1 menunjukkan hasil penelitian dari IDCERT yang menjadi laporan Dwi tahun 2018 menemukan pengaduan terkait cybercrime berasal dari malware sekitar $4.26 \%$ di bulan I dan meningkat hingga $9,46 \%$ di bulan III [2][3][4]. Malware atau yang sering disebut malicious software adalah sebuah perangkat lunak yang sengaja diciptakan untuk menyusup ke dalam sistem komputer beserta jaringannya tanpa diketahui oleh pemilik [5]. Tidak hanya merusak sistem secara langsung malware juga dapat membuat sistem rusak secara perlahan dengan cara memperbanyak aktivitas dari sistem atau menggandakan dirinya sendiri sehingga sistem akan melambat dan rusak secara perlahan. Saat ini malware tidak hanya berupa software saja tapi sudah merambah ke ranah aplikasi dengan sistem operasi android [6]. Berdasarkan statcounter system operasi android pada smartphone menembus angka $72.26 \%$ dari keseluruhan market sistem operasi mobile yang ada di dunia [7], hal ini memperkuat alasan mengapa perkembangan malware di Indonesia sangat cepat khususnya malware yang menyerang smartphone.

Pada umumnya dalam mendeteksi penyalahgunaan dan anomali pada sebuah aplikasi menggunakan static analisis atau dynamic analisis untuk mengekstraksi fitur dari sampel malware [8] Analisis static bertujuan untuk menganalisa kode dari sumber atau aplikasi dengan pola mencurigakan tanpa menjalankannya seperti mengurai file manifest pada aplikasi android [9]. Selain static, teknik analisa dynamic juga memiliki peran yang sangat penting dalam menganalisa malware pada android dengan menjalankan aplikasi pada sebuah perangkat virtual (sandbox) sehingga dapat menampilkan perilaku dari malware yang dijalankan.

Analisa dengan metode static lebih menguntungkan karena tidak terlalu banyak menggunakan resource akan tetapi sangat rentan terhadap penyamaran kode (code obfuscation), yang merupakan teknik umum dengan tujuan untuk mempersulit pembacaan sumber kode. Sebaliknya untuk analisis dynamic, code obfuscation tidak terlalu berpengaruh karena pembacaan aplikasi melalui aktivitas runtime, akan tetapi teknik ini memerlukan lebih banyak sumber daya [10]. Meningkatnya serangan malware pada sistem operasi android saat ini menjadi topik menarik untuk melakukan penelitian ini [11]. Seperti penguraian di atas tentang teknik analisa malware memiliki kelemahan satu sama lain, oleh sebab itu menggabungkan kedua teknik analisa yang sebelumnya diuraikan yaitu teknik static analysis dan dynamic analysis yang sering disebut hybrid analysis menggunakan framework MobSF yang kemudian akan dianalisa kembali bagian-bagian mana saja yang dicurigai sebagai malware dari aplikasi yang akan peneliti analisa.

\section{TINJUAN PUSTAKA}

\section{A. Malware}

Malware atau malicious software adalah sebuah perangkat lunak berbahaya yang digunakan untuk menyusupi komputer orang lain beserta jaringannya tanpa izin dari pemilik [5]. Malware terbagi menjadi beberapa bentuk seperti code,script, active content, dan perangkat lunak, malware juga mampu membuat perangkat keras bekerja lebih keras dari yang seharusnya karena perlu memfasilitasi jalannya program dari malware tersebut [12].

\section{B. Analisis Static}

Metode statis analis dilakukan tanpa benar-benar menjalankan programnya dan lebih seperti menyelidiki apa yang terjadi pada source code dengan tujuan utama yaitu untuk mengetahui kode berbahaya seperti apa yang tertanam dalam aplikasi tersebut [13].

\section{Analisis Dinamis}

Analisa malware secara dinamis dapat dilakukan dengan menjalankan virtual sandbox yang aman dan dalam tujuan guna mengetahui perilaku malware terhadap sistem seperti penambahan service, pengumpulan data, pembukaan port, dan penambahan jaringan [13].

\section{Hybrid Analysis}

Metode hybrid analysis adalah sebuah penggabungan dari teknik analisa statis dan teknik analisa dinamis dengan memeriksa source code yang diduga sebagai malware kemudian melihat perilaku dari malware tersebut setelah menginfeksi sistem [14]. Analisa hybrid ini dilakukan guna menutupi kekurangan dari kedua teknik tersebut.

\section{E. Sistem Operasi Android}

Sistem operasi android adalah sistem operasi mobile open source berbasis java dengan kernel linux 2.6 dan berfitur lengkap yang diciptakan untuk memenuhi kebutuhan konsumen. Aplikasi android yang di kembangkan dengan java lebih fleksibel terhadap platform yang digunakan, hal ini memberikan dorongan besar bagi pasar aplikasi android. Selain itu fitur-fitur yang dimiliki oleh android lebih menarik sehingga memiliki pertumbuhan yang sangat cepat terhadap pasar global.

Sistem operasi android memiliki keamanan salah satunya penambahan permission yang terdapat pada file "Androidmanifest.xml" di dalam aplikasinya hal ini bertujuan untuk memverifikasi penginstalan aplikasi kepada pengguna dengan memberitahukan permission yang diminta oleh aplikasi tersebut [15]. 


\section{F. MobSF}

Mobile Security Framework (MobSF) adalah framework pengujian otomatis bersifat open-source, yang mampu melakukan analisis statis dan dinamis dengan sangat mudah [16].

\section{METODOLOGI PENELITIAN}

Metodologi yang digunakan pada penelitian ini adalah kuantitatif dengan jenis pre-experimental design menggunakan one-shot case study. Maksud penelitian one-shot case study dalam penelitian ini yaitu tidak adanya kelas kontrol yang digunakan sebagai perbandingan dari kelas eksperimen. Lalu menelusuri lebih jauh hasil yang didapatkan serta melakukan pengukuran pada akhir penelitian. Adapun desain dari one-shot case study menurut Sugiyono dalam bukunya (2014:110) dapat digambarkan sebagai berikut :

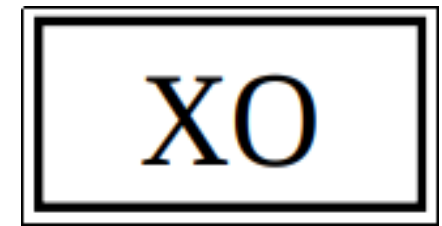

Gambar 2. One-Shot Case Study

Keterangan :

$\mathrm{X}=$ Treatment/perlakuan dengan menggunakan framework MobSF (Variabel Independen)

$\mathrm{O}=$ Observasi terhadap malware yang mendapatkan perlakuan (Variabel Dependen)

Dari paragraf di atas didapati sebuah kerangka berpikir yang digunakan pada penelitian ini yaitu untuk mencari hal-hal yang janggal pada malware yang menginfeksi perangkat android, dalam melakukan penelitian hybrid analysis, MobSF berperan penuh terhadap penelitian ini.

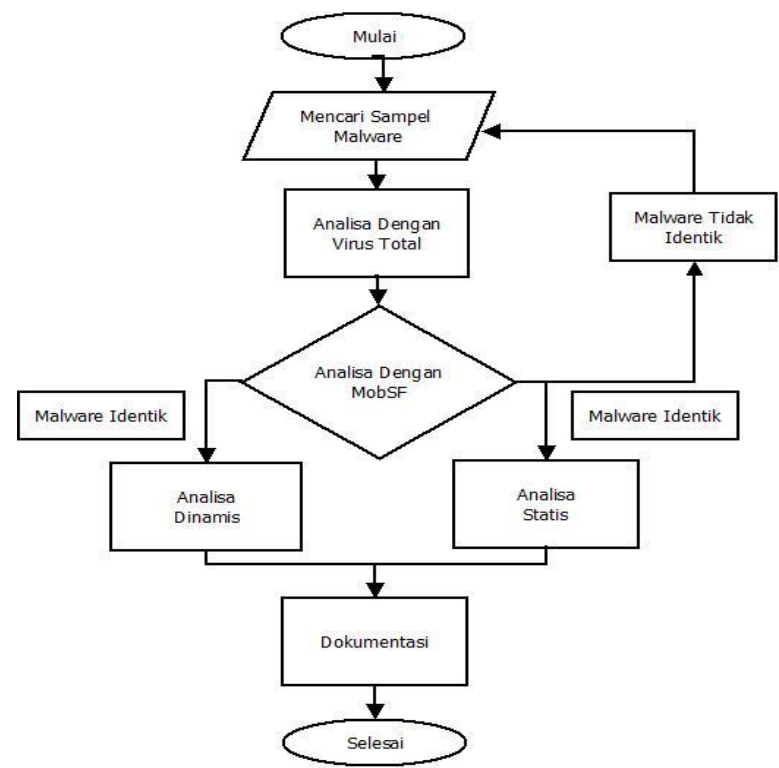

Gambar 3 Tahapan Penelitian Hybrid Analysis
Gambar 3 merupakan tahapan-tahapan yang akan dilakukan dalam penelitian ini. Menindaklanjuti hasil penelitian dari ID-CERT dengan meningkatnya pengaduan terkait cybercrime berasal dari malware sebesar 9,46\% pada tahun 2018, maka dalam penelitian ini akan berfokus pada analisa malware. Pencarian sampel malware dilakukan pada aplikasi yang sudah mengandung malware untuk dilakukan analisa selanjutnya. Dalam pemilihan sampel malware tersebut, didasarkan pada banyaknya serangan malware jenis adware dan trojan pada sistem operasi android. Selanjutnya, sampel dari malware yang sudah ditemukan akan dilakukan analisa dengan metode hybrid analysis.

Hybrid analysis yaitu menggabungkan dari 2 analisa, yaitu static analysis dan dynamic analysis. Metode analisa statis yang digunakan pada sampel malware adalah reverse engineering. Sampel malware dengan format file APK akan dilakukan reverse engineering untuk menelusuri sumber kode yang diduga malware dan agar dapat mengetahui lebih detail karakteristik dari perizinan yang ada di dalam aplikasi, sehingga dengan kombinasi dynamic analysis akan didapatkan hasil dari fungsionalitas dan perilaku terkait tingkat akurasi pendeteksian malware.

Dokumentasi akan menyimpan hasil dari setiap analisa yang dilakukan terhadap sampel aplikasi malware. Berbagai jenis tools yang digunakan seperti, MobSF dan scan sampel malware VirusTotal akan mendukung dalam proses pengumpulan informasi, dan kemudian akan disajikan dalam laporan penelitian.

\section{HASIL DAN PEMBAHASAN}

\section{A. Preparation Analysis}

Malware yang digunakan dalam objek penelitian adalah Bouncing Golf dan Riltok. Kedua malware tersebut dapat dilihat dalam Tabel 1 dan 2. Informasi lebih lengkap mengenai malware yang akan digunakan dalam penelitian sebagai berikut :

Tabel 1. Informasi malware bouncing golf (sumber: virustotal)

\begin{tabular}{|c|c|c|}
\hline No & \multicolumn{2}{|c|}{ Malware Bouncing Golf } \\
\hline 1 & SHA256 & $\begin{array}{l}\text { 55123ed4982fa135dbeda4 } \\
9969 \mathrm{ab} 68444125143 \mathrm{e} 369 \\
\text { 30fe1612d367f2fa615fc }\end{array}$ \\
\hline 2 & Rasio Deteksi & $24 / 61$ \\
\hline 3 & Waktu Analisis & $\begin{array}{l}2020-06-03 \\
\text { UTC }\end{array}$ \\
\hline 4 & Ukuuran File & $14.07 \mathrm{MB}$ \\
\hline 5 & Tipe File & APK \\
\hline
\end{tabular}

Informasi diperoleh dari VirusTotal yaitu sampel malware Bouncing Golf memiliki nilai checksum SHA256 atau Secure Hash Algorithm 55123ed4982fa1 35dbeda49969ab68444125143e36930fe1612d367f2fa $615 \mathrm{fc}$. Deteksi dengan rasio dari 61 antimalware dan hasil 24 antimalware dapat mendeteksi sampel 
malware Bouncing Golf. File sampel malware berukuran 14.07 MB dan tipe file APK. File APK merupakan tipe file yang umum digunakan pada sistem operasi android sebagai file distribusi dan pemasangan perangkat lunak atau aplikasi pada sistem android.

Tabel 2. Informasi malware riltok (sumber: virustotal)

\begin{tabular}{|c|c|c|}
\hline No & \multicolumn{2}{|c|}{ Malware Riltok } \\
\hline 1 & SHA256 & $\begin{array}{l}\text { 0497b6000a7a23e9e9b97 } \\
\text { 472bc2d3799caf49cbbea1 } \\
\text { 627ad4 d87ae6e0b7e2a98 }\end{array}$ \\
\hline 2 & Rasio Deteksi & $40 / 61$ \\
\hline 3 & Waktu Analisis & $\begin{array}{l}2019-09-27 \\
\text { UTC }\end{array}$ \\
\hline 4 & Ukuuran File & $992.55 \mathrm{~KB}$ \\
\hline 5 & Tipe File & APK \\
\hline
\end{tabular}

Informasi didapatkan dari VirusTotal yaitu sampel malware Riltok memiliki nilai checksum SHA256 atau Secure Hash Algorithm 0497b6000a7a23e9e9b9747 2bc2d3799caf49cbbe a1627ad4d87ae6e0b7e2a98. Deteksi dengan rasio dari 61 antimalware dan hasil 40 antimalware dapat mendeteksi sampel malware Riltok. File sampel malware berukuran $992.55 \mathrm{~KB}$ dan tipe file APK. File APK merupakan tipe file yang umum digunakan pada sistem operasi android sebagai file distribusi dan pemasangan perangkat lunak atau aplikasi pada sistem android.

Keaslian atau data integrity dari kedua sampel malware dapat dilakukan pemeriksaan dengan membandingkan informasi nilai checksum yang diperoleh dari Virus Total dan nilai checksum yang diperoleh menggunakan framework MobSF. Hasil pemeriksaan dari nilai checksum kedua sampel malware menggunakan framework MobSF dapat dilihat pada gambar 3 dan 4 .

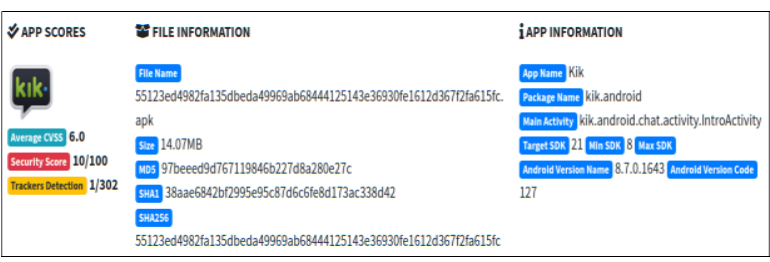

Gambar 4 Checksum Malware Bouncing Golf MobSF

Gambar 4 menunjukkan nilai checksum SHA256 dari sampel malware Bouncing Golf menggunakan framework MobSF. Tidak hanya terbatas pada file information, namun terlihat juga nilai application scores berdasar dari framework MobSF dan juga application information dari file APK atau sampel malware yang akan dilakukan analisa.

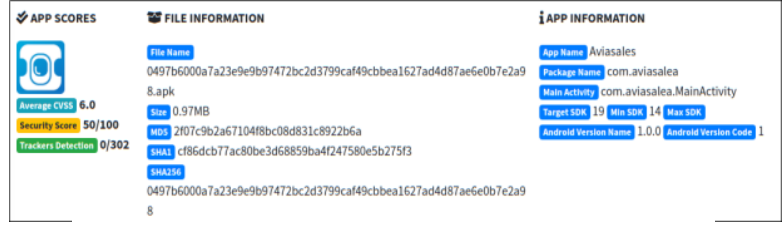

Gambar 5. Checksum Malware Riltok MobSF

Gambar 5 menunjukkan hasil dari nilai checksum SHA256 pada sampel malware Riltok dan memperlihatkan nilai yang diperoleh melalui framework MobSF identik dengan informasi nilai checksum yang diperoleh melalui VirusTotal, juga berarti bahwa sampel pada malware Riltok yang digunakan pada penelitian ini asli atau identik serta tidak mengalami modifikasi atau perubahan apapun. Perbandingan nilai checksum kedua sampel malware dapat dilihat pada Tabel 3.

Tabel 3. Perbandingan nilai checksum virustotal dengan MobSF

\begin{tabular}{|c|c|c|c|c|}
\hline \multirow[t]{2}{*}{ No } & \multirow[t]{2}{*}{ Malware } & \multicolumn{2}{|c|}{ Nilai Checksum } & \multirow[t]{2}{*}{ Definisi } \\
\hline & & $\begin{array}{l}\text { Virus } \\
\text { Total }\end{array}$ & MobSF & \\
\hline 1 & $\begin{array}{l}\text { Bouncin } \\
\text { g Golf }\end{array}$ & $\begin{array}{l}55123 \mathrm{ed} 4 \\
982 \mathrm{fa} 135 \mathrm{~d} \\
\text { beda4996 } \\
9 \mathrm{ab} 68444 \\
125143 \mathrm{e} 3 \\
6930 \mathrm{fe} 161 \\
2 \mathrm{~d} 367 \mathrm{f} 2 \mathrm{fa} \\
615 \mathrm{fc}\end{array}$ & $\begin{array}{l}55123 \mathrm{ed} 4 \\
982 \mathrm{fa} 135 \mathrm{~d} \\
\text { beda4996 } \\
9 \mathrm{ab} 68444 \\
125143 \mathrm{e} 3 \\
6930 \mathrm{fe} 161 \\
2 \mathrm{~d} 367 \mathrm{f} 2 \mathrm{fa} \\
615 \mathrm{fc}\end{array}$ & Identik \\
\hline 2 & Riltok & $\begin{array}{l}0497 \mathrm{~b} 600 \\
0 \mathrm{a} 7 \mathrm{a} 23 \mathrm{e} 9 \mathrm{e} \\
9 \mathrm{~b} 97472 \mathrm{~b} \\
\mathrm{c} 2 \mathrm{~d} 3799 \mathrm{c} \\
\text { af49cbbea } \\
1627 \mathrm{ad} 4 \mathrm{~d} \\
87 \mathrm{ae} 6 \mathrm{e} 0 \mathrm{~b} \\
7 \mathrm{e} 2 \mathrm{a} 98\end{array}$ & $\begin{array}{l}0497 \mathrm{~b} 600 \\
0 \mathrm{a} 7 \mathrm{a} 23 \mathrm{e} 9 \mathrm{e} \\
9 \mathrm{~b} 97472 \mathrm{~b} \\
\mathrm{c} 2 \mathrm{~d} 3799 \mathrm{c} \\
\text { af49cbbea } \\
1627 \mathrm{ad} 4 \mathrm{~d} \\
87 \mathrm{ae} 6 \mathrm{e} 0 \mathrm{~b} \\
7 \mathrm{e} 2 \mathrm{a} 98\end{array}$ & Identik \\
\hline
\end{tabular}

B. Static Analysis

Analisis statis yang dilakukan dalam penelitian ini menerapkan metode reverse engineering pada sampel malware untuk mendapatkan java source code. Tool yang digunakan dalam reverse engineering ini adalah MobSF, kemudian analisis dilakukan pada source code untuk mendapatkan kode kode yang terindikasi merusak atau terdapat program berbahaya.

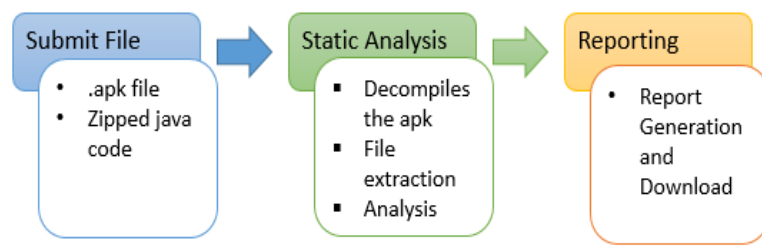

Gambar 6. Alur Analisis Static file APK dengan MobSF 
Gambar 6 merupakan alur reverse engineering pada sampel malware menggunakan framework MobSF. Tahapan pertama dalam analisis statis adalah dengan melakukan reverse engineering pada sampel malware dengan melakukan perubahan ekstensi file yang sebelumnya adalah *.apk menjadi *.zip menggunakan framework MobSF, hasil dari proses ini berupa ekstraksi dari file sampel malware menjadi data yang dapat dianalisa seperti pada alur proses gambar 6 . Hasil file ekstraksi dari framework MobSF adalah report.pdf atau hasil berupa laporan yang selanjutnya akan dianalisa untuk lebih mengetahui perizinan apa saja yang diminta oleh aplikasi dari sampel malware terhadap sistem serta source code dari file aplikasi yang sudah diubah melalui proses decompiler.

\section{Bouncing Golf Static Analysis}

1) Application Permission Analysis: File report.pdf dari hasil reverse engineering menggunakan framework MobSF mengandung seluruh informasi dari sebuah aplikasi, seperti file information, application information, application components, certificate information, application permissions, APKID analysis, manifest analysis, code analysis, domain malware check, firebase database, emails, dan trackers. Seluruh informasi yang didapatkan tersebut akan dianalisa dengan fokus utama pada application permission dan code analysis. Application permission adalah informasi hak akses atau perizinan yang diminta oleh sampel malware.

Informasi perizinan yang didapatkan selanjutnya dilakukan pembagian berdasar pada tingkat keamanan sesuai dengan potensi atau hasil kerusakan yang disebabkan oleh malware Bouncing Golf. Detail lengkap mengenai informasi perizinan sampel malware Bouncing Golf dapat dilihat pada Tabel 4.

Tabel 4. Tingkat keamanan perizinan malware bouncing golf

\begin{tabular}{|l|l|l|l|}
\hline No & \multicolumn{1}{|c|}{ Permission } & Status & Information \\
\hline 1 & $\begin{array}{l}\text { android.permission } \\
\text {.INTERNET }\end{array}$ & Dangerous & $\begin{array}{l}\text { Full internet } \\
\text { access }\end{array}$ \\
\hline 2 & $\begin{array}{l}\text { android.permission } \\
\text {.READ_PHONE_S } \\
\text { TATE }\end{array}$ & Dangerous & $\begin{array}{l}\text { Read phone } \\
\text { state and } \\
\text { identity }\end{array}$ \\
\hline $\begin{array}{l}\text { android.permission } \\
\text { TS }\end{array}$ & Dangerous & $\begin{array}{l}\text { Read contact } \\
\text { data }\end{array}$ \\
\hline 4 & $\begin{array}{l}\text { android.permission } \\
\text {.WRITE_EXTERN } \\
\text { AL_STORAGE }\end{array}$ & Dangerous & $\begin{array}{l}\text { Read/modify } \\
\text { /delete SD } \\
\text { card contents }\end{array}$ \\
\hline
\end{tabular}

\begin{tabular}{|c|c|c|c|}
\hline 5 & $\begin{array}{l}\text { android.permission } \\
\text {.WAKE_LOCK }\end{array}$ & Dangerous & $\begin{array}{l}\text { Prevent } \\
\text { phone from } \\
\text { sleeping }\end{array}$ \\
\hline 6 & $\begin{array}{l}\text { kik.android.permis } \\
\text { sion.CONTACT }\end{array}$ & Dangerous & $\begin{array}{l}\text { Unknown } \\
\text { permission } \\
\text { from android } \\
\text { reference }\end{array}$ \\
\hline 7 & $\begin{array}{l}\text { com.android.vendi } \\
\text { ng.BILLING }\end{array}$ & Dangerous & $\begin{array}{l}\text { Unknown } \\
\text { permission } \\
\text { from android } \\
\text { reference }\end{array}$ \\
\hline 8 & $\begin{array}{l}\text { android.permission } \\
\text {.ACCESS_FINE_L } \\
\text { OCATION }\end{array}$ & Dangerous & $\begin{array}{l}\text { Fine (GPS) } \\
\text { location }\end{array}$ \\
\hline 9 & $\begin{array}{l}\text { android.permission } \\
\text {.ACCESS_COARS } \\
\text { E_LOCATION }\end{array}$ & Dangerous & $\begin{array}{l}\text { Coarse } \\
\text { (network } \\
\text { based) } \\
\text { location }\end{array}$ \\
\hline 10 & $\begin{array}{l}\text { ancdroid.permisson } \\
\text {.CAMERA }\end{array}$ & Dangerous & $\begin{array}{l}\text { Take pictures } \\
\text { and videos }\end{array}$ \\
\hline 11 & $\begin{array}{l}\text { android.permission } \\
\text {.RECORD_AUDI } \\
\text { O }\end{array}$ & Dangerous & Record audio \\
\hline 12 & $\begin{array}{l}\text { android.permission } \\
\text {.STORAGE }\end{array}$ & Dangerous & $\begin{array}{l}\text { Unknown } \\
\text { permission } \\
\text { from android } \\
\text { reference }\end{array}$ \\
\hline 13 & $\begin{array}{l}\text { android.permission } \\
\text {.SYSTEM_ALER } \\
\text { T_WINDOW }\end{array}$ & Dangerous & $\begin{array}{l}\text { Display } \\
\text { system alerts }\end{array}$ \\
\hline 14 & $\begin{array}{l}\text { android.permission } \\
\text {.QUICKBOOT_P } \\
\text { OWERON }\end{array}$ & Dangerous & $\begin{array}{l}\text { Unknown } \\
\text { permission } \\
\text { from android } \\
\text { reference }\end{array}$ \\
\hline 15 & $\begin{array}{l}\text { android.permission } \\
\text {.READ_SMS }\end{array}$ & Dangerous & $\begin{array}{l}\text { Read SMS or } \\
\text { MMS }\end{array}$ \\
\hline 16 & $\begin{array}{l}\text { android.permission } \\
\text {.WRITE_SMS }\end{array}$ & Dangerous & $\begin{array}{l}\text { Edit SMS or } \\
\text { MMS }\end{array}$ \\
\hline 17 & $\begin{array}{l}\text { com.android.brows } \\
\text { er.permission.REA } \\
\text { D_HISTORY_BO }\end{array}$ & Dangerous & $\begin{array}{l}\text { Read } \\
\text { browser } \\
\text { history and }\end{array}$ \\
\hline
\end{tabular}




\begin{tabular}{|c|c|c|c|}
\hline & OKMARKS & & bookmarks \\
\hline 18 & $\begin{array}{l}\text { android.permission } \\
\text {.GET_TASK }\end{array}$ & Dangerous & $\begin{array}{l}\text { Retrieve } \\
\text { running } \\
\text { applications }\end{array}$ \\
\hline 19 & $\begin{array}{l}\text { android.permission } \\
\text {.CALL_PHONE }\end{array}$ & Dangerous & $\begin{array}{l}\text { Directly call } \\
\text { phone } \\
\text { numbers }\end{array}$ \\
\hline 20 & $\begin{array}{l}\text { android.permission } \\
\text {.SEND_SMS }\end{array}$ & Dangerous & $\begin{array}{l}\text { Send SMS } \\
\text { messages }\end{array}$ \\
\hline 21 & $\begin{array}{l}\text { android.permission } \\
\text {.WRITE_SETTIN } \\
\text { GS }\end{array}$ & Dangerous & $\begin{array}{l}\text { Modify } \\
\text { global } \\
\text { system } \\
\text { settings }\end{array}$ \\
\hline 22 & $\begin{array}{l}\text { android.permission } \\
\text {.READ_EXTERN } \\
\text { AL_STORAGE }\end{array}$ & Dangerous & $\begin{array}{l}\text { Read SD } \\
\text { card contents }\end{array}$ \\
\hline 23 & $\begin{array}{l}\text { android.permission } \\
\text { _RECEIVE_SMS }\end{array}$ & Dangerous & $\begin{array}{l}\text { Receive } \\
\text { SMS }\end{array}$ \\
\hline 24 & $\begin{array}{l}\text { android.permission } \\
\text {.PROCESS_OUTG } \\
\text { OING_CALLS }\end{array}$ & Dangerous & $\begin{array}{l}\text { Intercept } \\
\text { outgoing } \\
\text { calls }\end{array}$ \\
\hline 25 & $\begin{array}{l}\text { android.permission } \\
\text {.READ_CALL_L } \\
\text { OG }\end{array}$ & Dangerous & $\begin{array}{l}\text { Read user } \\
\text { call log }\end{array}$ \\
\hline 26 & $\begin{array}{l}\text { android.permission } \\
\text {.WRITE_CALL_L } \\
\text { OG }\end{array}$ & Dangerous & $\begin{array}{l}\text { Write user } \\
\text { call log data }\end{array}$ \\
\hline
\end{tabular}

2) Code Review: Tahap ini merupakan proses lanjutan dari hasil permission analysis, setelah semua perizinan yang diminta oleh aplikasi malware terhadap sistem ditemukan maka dilakukan analisa lebih lanjut dalam bentuk java source code. Report yang didapatkan dari hasil analisis menggunakan framework MobSF tidak hanya dalam bentuk laporan PDF, namun juga file ekstraksi dari sampel malware melalui proses decompile dan file extraction menjadi source code java, dengan ini struktur dan source code dapat dianalisa.
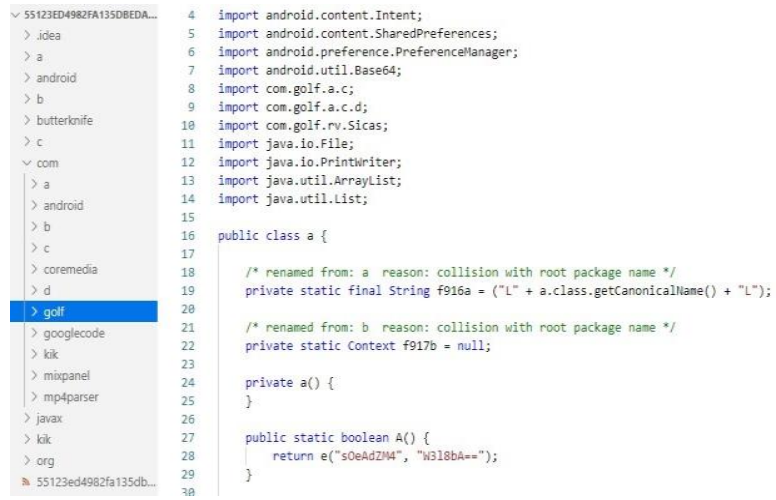

Gambar 7. Struktur Source Code Malware Bouncing Golf

Gambar 7 menunjukkan struktur dari sampel malware Bouncing Golf setelah melalui proses reverse engineering menggunakan framework MobSF. Analisis statis digunakan dalam melakukan analisis fungsi-fungsi yang ada pada source code dari sampel malware. Tahapan ini diperlukan dalam mencari kode program yang dapat bersifat malicious atau berbahaya, dan sampel malware Bouncing Golf masuk dalam kategori spyware. Beberapa fungsi program malicious ditemukan dalam static analysis, di mana program malicious disisipkan dalam folder golf.
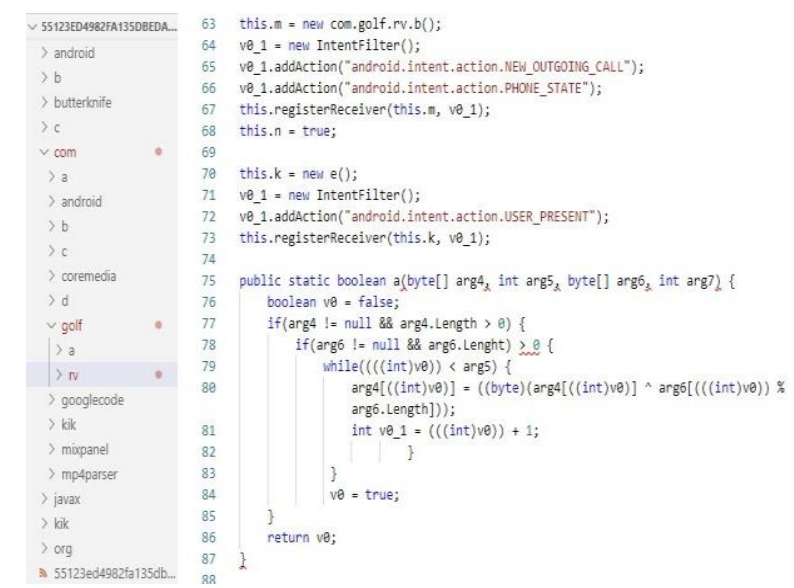

Gambar 8. Analisa Fungsi Source Code Call Phone Monitor

Gambar 8 merupakan hasil dari analisa statis pada source code malware Bouncing Golf dan ditemukan sampel malware memiliki fungsi untuk melakukan pemantauan dan merekam panggilan telepon yang sedang terjadi pada perangkat smartphone pengguna, selain itu ada data call $\operatorname{logs}$, contacts, accounts, browser history dan bookmarks, SMS messages, phone information, dan file media seperti image dan video yang menjadi sasaran dari program Bouncing Golf. Data yang dicuri akan dikumpulkan dan dilakukan enkripsi menggunakan operasi XOR sederhana, kemudian data tersebut akan dikirimkan ke server Command \& Control menggunakan metode HTTP POST. 


\section{Riltok Static Analysis}

1) Application Permission Analysis: Dalam proses permission analysis yang akan dilakukan sama seperti pada sampel malware Bouncing Golf. Teknik reverse engineering dilakukan dengan menggunakan framework MobSF untuk melakukan decompile file APK pada malware Riltok. Hasil dari proses decompile berupa file report.pdf yang selanjutnya akan dianalisa berdasar hasil laporan tersebut. Analisa berfokus pada application permission analysis untuk mengetahui perizinan yang diminta oleh sampel malware dan dampak terhadap sistem, seperti terlihat pada Table 5.

Tabel 5. Tingkat keamanan perizinan malware riltok

\begin{tabular}{|c|c|c|c|}
\hline No & Permission & Status & Information \\
\hline 1 & $\begin{array}{l}\text { android.permission } \\
\text {.INTERNET }\end{array}$ & Dangerous & $\begin{array}{l}\text { Full internet } \\
\text { access }\end{array}$ \\
\hline 2 & $\begin{array}{l}\text { android.permission } \\
\text {.USES_POLICY_F } \\
\text { ORCE_LOCK }\end{array}$ & Dangerous & $\begin{array}{l}\text { Unknown } \\
\text { permission } \\
\text { from android } \\
\text { reference }\end{array}$ \\
\hline 3 & $\begin{array}{l}\text { android.permission } \\
\text {.WAKE_LOCK }\end{array}$ & Dangerous & $\begin{array}{l}\text { Prevent phone } \\
\text { from sleeping }\end{array}$ \\
\hline 4 & $\begin{array}{l}\text { android.permission } \\
\text {.WRITE_SETTIN } \\
\text { GS }\end{array}$ & Dangerous & $\begin{array}{l}\text { Modify global } \\
\text { system } \\
\text { settings }\end{array}$ \\
\hline 5 & $\begin{array}{l}\text { android.permission } \\
\text {.SYSTEM_ALER } \\
\text { T_WINDOW }\end{array}$ & Dangerous & $\begin{array}{l}\text { Display } \\
\text { system-level } \\
\text { alerts }\end{array}$ \\
\hline 6 & $\begin{array}{l}\text { android.permission } \\
\text {.REAL_GET_TAS } \\
\text { K }\end{array}$ & Dangerous & $\begin{array}{l}\text { Unknown } \\
\text { permission } \\
\text { from android } \\
\text { reference }\end{array}$ \\
\hline 7 & $\begin{array}{l}\text { android.permission } \\
\text {.READ_PHONE_S } \\
\text { TATE }\end{array}$ & Dangerous & $\begin{array}{l}\text { Read phone } \\
\text { state and } \\
\text { identity }\end{array}$ \\
\hline 8 & $\begin{array}{l}\text { android.permission } \\
\text {.RECEIVE_SMS }\end{array}$ & Dangerous & Receive SMS \\
\hline 9 & $\begin{array}{l}\text { android.permission } \\
\text {.READ_SMS }\end{array}$ & Dangerous & $\begin{array}{l}\text { Read SMS or } \\
\text { MMS }\end{array}$ \\
\hline 10 & $\begin{array}{l}\text { android.permission } \\
\text {.SEND_SMS }\end{array}$ & Dangerous & $\begin{array}{l}\text { Send SMS } \\
\text { messages }\end{array}$ \\
\hline
\end{tabular}

\begin{tabular}{|c|l|l|l|}
\hline 11 & $\begin{array}{l}\text { android.permisson. } \\
\text { CALL_PHONE }\end{array}$ & Dangerous & $\begin{array}{l}\text { Directly call } \\
\text { phone } \\
\text { numbers }\end{array}$ \\
\hline 12 & $\begin{array}{l}\text { android.permission } \\
\text {.CHANGE_WIFI_ } \\
\text { STATE }\end{array}$ & Dangerous & $\begin{array}{l}\text { Change Wi-Fi } \\
\text { status }\end{array}$ \\
\hline 13 & $\begin{array}{l}\text { android.permission } \\
\text {.CHANGE_NETW } \\
\text { ORK_STATE }\end{array}$ & Dangerous & $\begin{array}{l}\text { Change } \\
\text { network } \\
\text { connectivity }\end{array}$ \\
\hline 14 & $\begin{array}{l}\text { android.permission } \\
\text {.GET_TASK }\end{array}$ & Dangerous & $\begin{array}{l}\text { Received } \\
\text { running } \\
\text { applications }\end{array}$ \\
\hline
\end{tabular}

2) Code Review: Tahap ini merupakan proses lanjutan dari hasil permission analysis, setelah semua perizinan yang diminta oleh aplikasi sampel malware terhadap sistem ditemukan maka akan dilakukan analisa lebih lanjut dalam bentuk java source code. Report yang didapatkan dari hasil analisis menggunakan framework MobSF tidak hanya dalam bentuk laporan PDF, namun juga file ekstraksi dari sampel malware melalui proses decompile dan file extraction menjadi source code java, dengan ini struktur dan source code dapat dianalisa.
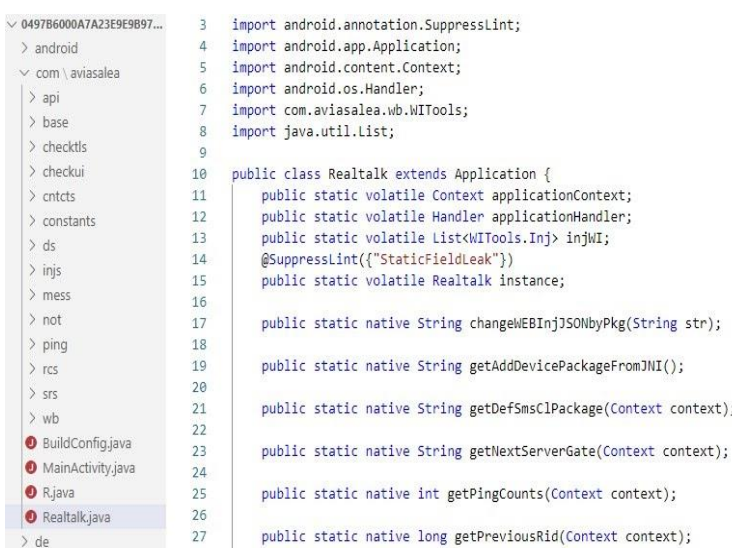

Gambar 9 Struktur Source Code Java Malware Riltok

Gambar 9 merupakan struktur dari sampel malware Riltok setelah melalui proses reverse engineering menggunakan framework MobSF. Analisa statis digunakan dalam melakukan menganalisa fungsi-fungsi yang ada pada source code, tahapan ini sama seperti pada sampel malware sebelumnya yang diperlukan dalam mencari kode program yang dapat bersifat malicious atau berbahaya, dan sampel malware Riltok masuk dalam kategori phising. Beberapa fungsi program malicious ditemukan pada sampel malware Riltok diantaranya adalah menjadikan malware sebagai default SMS application, dan 
menampilkan halaman pembayaran dengan detail kartu bank.

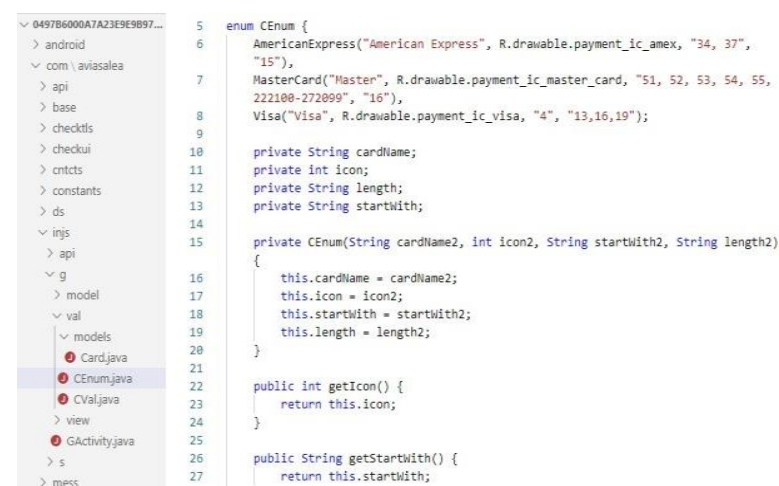

Gambar 10. Analisa Fungsi Source Code Fake Google Play Request Bank Card Details

Gambar 10 menunjukkan hasil dari analisa statis pada source code malware Riltok dan ditemukan sampel malware memiliki fungsi utama dalam mencuri data kartu kredit dan mengirimkan data tersebut ke server Command \& Control. Malware Riltok menampilkan halaman pembayaran palsu dari Service Google Play yang meminta detail kartu bank serta menampilkan halaman pembayaran melalui browser dengan menyerupai pembayaran dari mobile banking. Setelah pengguna memasukan detail kartu bank pada halaman pembayaran palsu, malware akan melakukan validasi dasar seperti periode kartu, nomor kartu, jumlah nomor kartu, panjang CVC dan melakukan pencocokan data dengan daftar blacklist kartu yang telah disiapkan oleh malware Riltok.

\section{E. Dynamic Analysis}

Dalam menganalisis sebuah malware android khususnya analisa dinamis pada umumnya memerlukan sebuah environment yang aman atau biasanya disebut virtual lab. Perangkat virtual dalam proses analisa dinamis ini menggunakan virtual lab (emulator) android dari Genymotion dengan versi android 8.1 dan API level 27 (Oreo) yang dihubungkan dengan MobSF untuk proses analisa dinamis dengan menggunakan jaringan local area network (LAN).

Sampel malware yang digunakan dalam analisis dinamis sama dengan sampel pada analisis statis, yang kemudian dijalankan (install) dan dilakukan analisa permission, juga dilakukan analisa kembali terhadap karakteristik dari malware Bouncing Golf dan Riltok.

\section{F. Bouncing Golf Dynamic Analysis}

1) Installing and Running: Pemasangan malware Bouncing Golf yang menyerupai aplikasi KIK (aslinya adalah sebuah aplikasi media chatting online) menampilkan beberapa perizinan yang diminta oleh malware Bouncing Golf sebagai syarat penginstalan. Melihat beberapa perizinan yang diminta oleh malware Bouncing Golf untuk melakukan install atau pemasangan aplikasi, beberapa perizinan yang pada dasarnya tidak dibutuhkan dan dapat dipastikan bahwa malware Bouncing Golf sedang mencoba menarik informasi dari penggunanya.

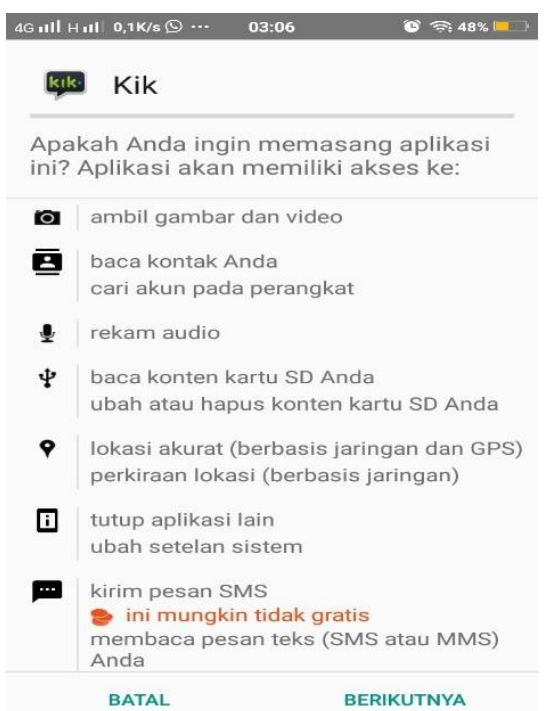

Gambar 11. Perizinan Instalasi Malware Bouncing Golf

Gambar 11 menunjukkan tampilan perizinan saat pemasangan malware Bouncing Golf. Sampel malware Bouncing Golf yang sebelumnya telah terpasang kemudian dijalankan pada emulator dan dilakukan analisa activity. Pada tampilan pertama dari malware Bouncing Golf, didapati tampilan yang menyerupai aplikasi KIK dan terdapat dua pilihan yaitu register dan login, dari ke-2 pilihan tersebut tidak ada yang benar-benar bekerja $100 \%$ dikarenakan menu register dan menu login tidak terhubung atau tidak terkoneksi dengan database yang kemudian menyebabkan tidak dapat login ke dalam aplikasi tersebut.

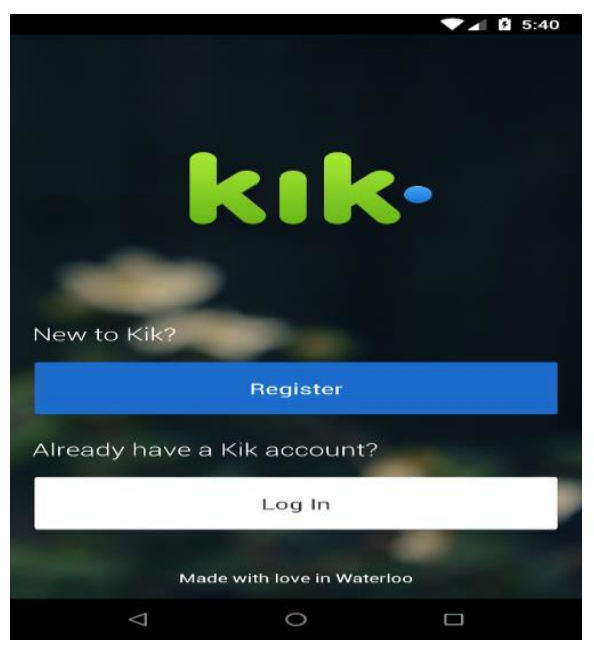

Gambar 12. Register dan Log In Malware Bouncing Golf 
Gambar 12 menunjukkan tampilan dari menu login dan register dari malware Bouncing Golf. Terlihat bahwa akses masuk atau menjalankan aplikasi ini diharuskan untuk mendaftar terlebih dahulu dengan memberikan informasi pribadi pengguna seperti pada umumnya, namun karena tidak terkoneksi dengan database maka tidak didapatkan akses untuk masuk ke dalam aplikasi tersebut.

2) Traffic Analisis: HTTP tools adalah sebuah tool perekam traffic HTTP yang terdapat pada analisa dinamis MobSF. Analisa traffic dari sampel malware Bouncing Golf yang dilakukan dengan MobSF menunjukkan sebuah request pada suatu halaman website.

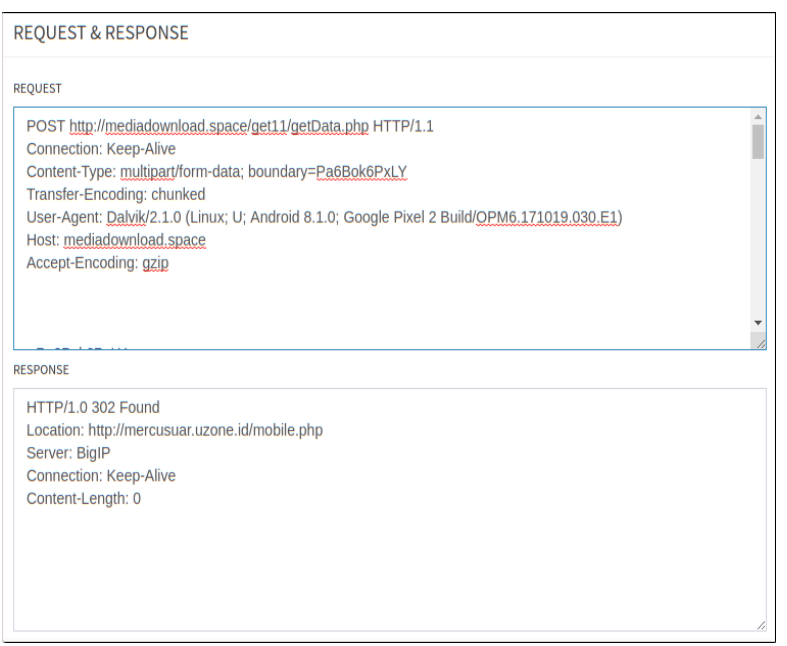

\section{Gambar 13. Monitoring Traffic Malware Bouncing} Golf menggunakan HTTP tools MobSF

Gambar 13 menunjukkan monitoring yang dilakukan menggunakan HTTP tools pada framework MobSF. Hasil dari monitoring ini menemukan sebuah respons ke alamat website yaitu http://mediadownload.space/get11/getdata.php dengan metode POST. Respons yang didapat dari request sebelumnya yaitu 302, yang artinya website sementara dialihkan hal tersebut disebabkan karena adanya gangguan terhadap Domain Name Server (DNS) yang mengarah pada website tersebut.

\section{G. Riltok Dynamic Analysis}

1) Installing and Running: Pemasangan atau proses install malware Riltok yang menyerupai aplikasi AVIASALES(aslinya adalah sebuah aplikasi pembelian tiket pesawat online) menampilkan beberapa perizinan yang diminta oleh sampel malware Riltok sebagai syarat aplikasi dapat dipasang atau install. Namun perizinan yang diminta oleh malware Riltok sangat tidak sesuai dengan fungsi dari aplikasinya, seperti membaca dan menerima SMS atau telepon yang pada dasarnya tidak diperlukan untuk sebuah aplikasi pembelian tiket online.

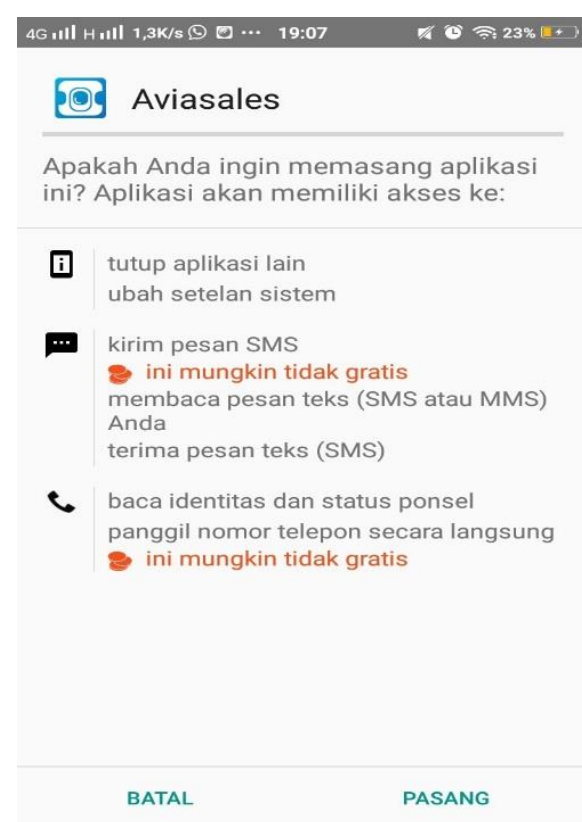

Gambar 14. Perizinan Instalasi Malware Riltok

Gambar 14 merupakan tampilan perizinan saat pemasangan malware Riltok. Sampel malware yang sebelumnya telah terpasang kemudian dijalankan pada perangkat virtual dan dilakukan analisa activity. Pada tampilan utama pada malware Riltok menampilkan activation devices admin dan meminta kepada pengguna untuk segera melakukan aktivasi yang kemudian memunculkan sebuah form credit card dan terdapat notifikasi play protect disable.

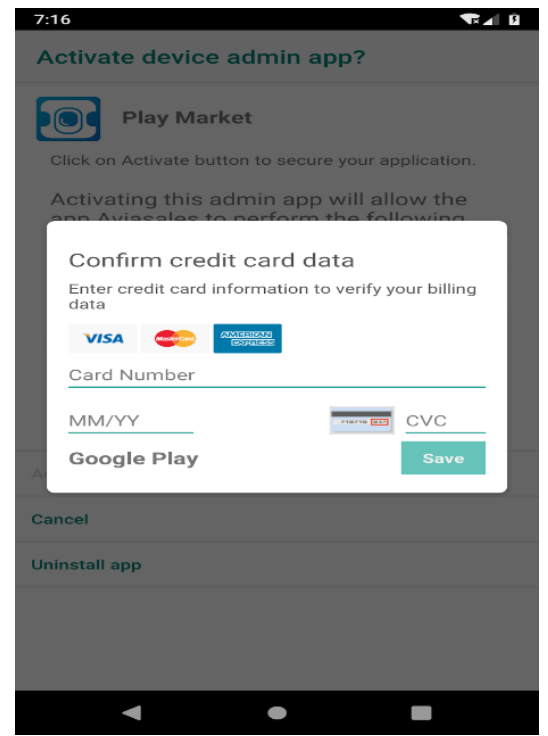

Gambar 14. Form Credit Card Aktivasi pada Malware Riltok

Gambar 14 menunjukkan tampilan form credit card pada saat aktivasi malware Riltok. Setelah pengguna memasukan detail kartu bank pada halaman pembayaran palsu, malware akan melakukan validasi 
dengan kecocokan pada nomor kartu debit atau credit yang dimasukkan.

2) Traffic Analysis: Hasil monitoring traffic dari malware Riltok yang dijalankan pada perangkat virtual menunjukkan sebuah usaha komunikasi antara malware dengan server C\&C dengan metode GET, Terlihat pada gambar 14 .

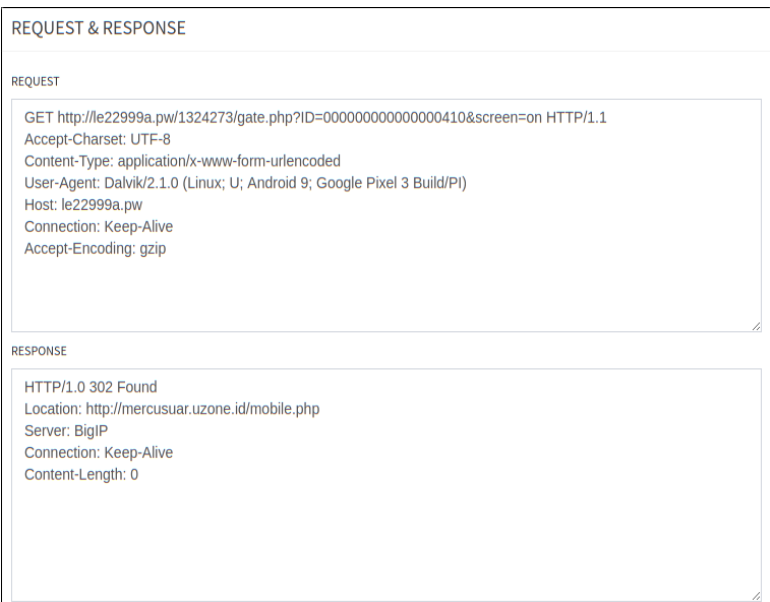

Gambar 15. Monitoring Traffic Malware Riltok menggunakan HTTP tools MobSF

Pada gambar 15 traffic HTTP yang dilakukan proses request oleh malware Riltok dengan metode GET pada alamat http://le22999a.pw /1324273/gate.php memberikan respons 302 dan Domain Name Server (DNS) dibelokkan pada sebuah website http://mercusuar.uzone.id, yang artinya DNS tidak dapat mentranslasikan alamat IP dari server malware Riltok sehingga kemungkinan besar akses C\&C pada sampel malware Riltok dan server telah dimatikan.

\section{H. Pencegahan}

Upaya dalam melakukan pencegahan dan melindungi smartphone Android dari infeksi malware adalah sebagai berikut :

- Pastikan hanya memasang aplikasi android dari sumber terpercaya seperti Google Play Store dan hindari pemasangan aplikasi dari sumber yang tidak dipercaya.

- Hiraukan SMS yang berisi tautan mencurigakan seperti link dari sebuah alamat website.

- Perhatikan juga permission atau perijinan yang diminta aplikasi terhadap sistem android.

- Pastikan selalu update firmware sistem android pada smartphone.

- Pasang antivirus untuk platform android dan update secara berkala database dari antivirus tersebut.

\section{KESIMPULAN}

Dari hasil analisis sampel malware Bouncing Golf dan Riltok menggunakan MobSF dengan metode static analysis dan dynamic analysis menggunakan virtual lab (emulator) android dari Genymotion dengan versi android 8.1 dan API level 27 (Oreo) telah suskses mendapatkan beberapa karakteristik dari kedua malware. Bouncing Golf melakukan pemantauan dan merekam aktivitas yang dilakukan pengguna smartphone android. Sedangkan malware Riltok memiliki karakteristik dalam mencuri data kartu kredit dengan menampilkan halaman billing palsu. Kedua malware memiliki karakteristik yang sama, yaitu data akan dikirimkan ke server $\mathrm{C} \& \mathrm{C}($ Command \& Control Server). Upaya pencegahan yang dapat dilakukan untuk menghindari infeksi malware pada smartphone android yaitu dengan memastikan hanya memasang aplikasi android dari sumber terpercaya seperti Google Play Store, dan hiraukan SMS yang berisi tautan mencurigakan, serta pastikan selalu update firmware sistem android pada smartphone.

\section{SARAN}

Saran yang dapat diberikan untuk pengerjaan pada penelitian berikutnya, diharapkan melalui laporan yang didapatkan ini dapat dilakukan pengembangan dalam melakukan analisa yang lebih efektif dan otomatis, seperti penerapan machine learning pada malware yang bersifat masif. Penelitian dengan teknik yang sama juga bisa dilakukan dalam investigasi serta analisis malware khususnya pada smartphone dengan platform android untuk mempelajari karakteristik malware yang terus berkembang.

\section{DAFTAR PUSTAKA}

[1] W. Pranoto, "Malicious Software Analysis," Cyber Secur. dan Forensik Digit., vol. 1, no. 2, pp. 2019, 62-66, doi: 10.4018/9781605660608.ch030.

[2] ID-CERT, "Laporan Dwi Bulan I 2018." [Online]. Available: https://cert.id/media/files/01__UMUM_Dwi_Bulan_I_2018.pdf. [Accessed: 26-Mar-2020].

[3] ID-CERT, "Laporan Dwi Bulan II 2018." [Online]. Available: https://cert.id/media/files/02_-

_UMUM_Dwi_Bulan_II_2018.pdf.

[Accessed: 26-Mar-2020].

[4] ID-CERT, "Laporan Dwi Bulan III 2018." [Online].

Available: https://www.cert.or.id/media/files/03_-

_UMUM_Dwi_Bulan_III_2018.pdf.

[Accessed: 26-Mar-2020].

Y. A. Utomo, S. Juli, I. Ismail, and T. Z. S. T, "Membangun Sistem Analisis Malware Pada 
Aplikasi Android Dengan Metode Reverse Engineering Menggunakan Remnux," vol. 4, no. 3, pp. 2000-2012, 2018.

[6] R. Novrianda, Y. N. Kunang, and P. . Shaksono, "Analisis Forensik Pada Platform Android," Konf. Nas. ilmu Komput., pp. 141148, 2014.

[7] GlobalStats, "Mobile Operating System Market Share Worldwide on Statcounter." [Online]. Available: https://gs.statcounter.com/os-marketshare/mobile/worldwide. [Accessed: 27-Mar2020].

[8] F. Ghaffari, M. Abadi, and A. Tajoddin, "AMD-EC: Anomaly-based Android malware detection using ensemble classifiers," 2017 25th Iran. Conf. Electr. Eng. ICEE 2017, no. 1CEE, pp. 2247-2252, 2017, doi: 10.1109/IranianCEE.2017.7985436.

[9] B. A. Wichmann, A. A. Canning, D. L. Clutterbuck, L. A. Winsborrow, N. J. Ward, and D. W. R. Marsh, "Industrial perspective on static analysis," Softw. Eng. J., vol. 10, no. 2, pp. 69-75, 1995, doi: 10.1049/sej.1995.0010.

[10] V. Rastogi, Y. Chen, and X. Jiang, "DroidChameleon: Evaluating Android antimalware against transformation attacks," ASIA CCS 2013 - Proc. 8th ACM SIGSAC Symp. Information, Comput. Commun. Secur., pp. 329-334, 2013, doi: $10.1145 / 2484313.2484355$.

[11] A. F. Febrianto, A. Budiono, P. Studi, S. Informasi, F. R. Industri, and U. Telkom, "Analisis Malware Pada Sistem Operasi Android Menggunakan Metode Network Traffic Analysis Malware Analysis in Android Operating System Using Network," vol. 6, no. 2, pp. 7837-7844, 2019.

[12] Mobliciti, "The current state of mobile malware on Mobliciti." [Online]. Available: https://mobliciti.com/the-current-state-ofmobile-malware. [Accessed: 29-Mar-2020].

[13] K. Alfalqi, R. Alghamdi, and M. Waqdan, "Android Platform Malware Analysis," Int. J. Adv. Comput. Sci. Appl., vol. 6, no. 1, pp. 140 146, 2015, doi: 10.14569/ijacsa.2015.060120.

[14] N. Zalavadiya and P. Sharma, "A Methodology of Malware Analysis, Tools and Technique for windows platform-RAT Analysis," Int. J. Innov. Res. Comput. Commun. Eng., vol. 5, no. 3, pp. 8198-8205, 2017, doi: 10.15680/IJIRCCE.2017.

[15] A. S. Rusdi, N. Widiyasono, and H. Sulastri, "Analisis Infeksi Malware Pada Perangkat Android Dengan Metode Hybrid Analysis," no. 24, 2019.

[16] A. Kartono, A. Sularsa, and S. J. I. Ismail, "Membangun Sistem Pengujian Keamanan
Aplikasi Android Menggunakan Mobsf," vol. 5, no. 1, pp. 146-151, 2019.

[17] Sugiyono, Metode Penelitian Pendidikan Pendekatan Kuantitatif, Kualitatif, dan R\&D, Bandung: Alfabeta, 2014. 